PIOTR CELEWICZ*

\title{
Smart City Expo World Congress, Barcelona 2017 - inteligentne rozwiązania przyszłości miast ${ }^{1}$
}

Smart City Expo World Congress, Barcelona 2017 - intelligent solutions of the future of cities ${ }^{1}$

\section{Streszczenie}

Niniejszy artkuł dotyczy opisu wydarzenia SMART CITY EXPO WORLD CONGRESS w Barcelonie. Autor przedstawia najnowsze trendy, idee oraz mody towarzyszące mieszkańcom nowoczesnych miast. Ponadto zawarto tu zbiór wybranych dobrych praktyk odnoszacych sie do rozwoju, polityki, czy zarzadzania strukturami zurbanizowanymi. Pojęcie miast inteligentnych dotyczy dziś niemal każdej dziedziny życia i funkcjonowania tych struktur.

\section{Abstract}

This article concerns the description of the SMART CITY EXPO WORLD CONGRESS event in Barcelona. The author presents the latest rends, ideas and fashions accompanying the inhabitants of modern cities. In addition, a set of selected good practices relating to the development, policy or management of urbanized structures is included here. The concept of smart cities today applies to almost every area of life and functioning of these structures.

Stowa kluczowe: SMART CITY EXPO WORLD CONGRESS, inteligentne miasta, rozwój miast

Świat, czyli „wszystko istniejące", składa się z „rzeczy", o których można się dowiedziec dzięk" ", informacji. Tę , informacje" rzeczy wprost mogą "wysyłac" (jak człowiek
mówiący, jak ksiażka czytana, jak pejzaż oglądany), albo też poprzez tancuchy „zmystowo-umystowych rozumowań [...] Każda bez wyjątku nowa technologia ma awers korzyści i zarazem
rewers nowych, nieznanych dotychczas bied.

Stanisław Lem - Bomba megabitowa²

W dobie dynamicznie rozwijającej się nadprodukcji elektroniki i oprogramowania zasypywani jesteśmy mnogością rozwiązan, ktore przeniknęly do codziennego zycia. Czy technologia naprawdę nam służy? Czy może jednak jesteśmy już jej niewolnikami, realizując paradygmat społeczeństwa informacyjnego? Czy przypadkiem nie wyszukujemy pretekstów, aby korzystać z nowości i gadżetów, bo jesteśmy od nich zależn i często są one ucieczką od rzeczywistości, w wirtualny świat gier, zabaw lub zaspokajania wiedzy, emocji, czy też zastapieniem prostych czynności, wykonywanych wcześniej przez pracownikow instytucji (jak np. banki, urzedy). Nowoczesne

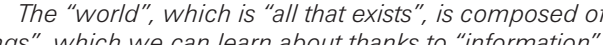

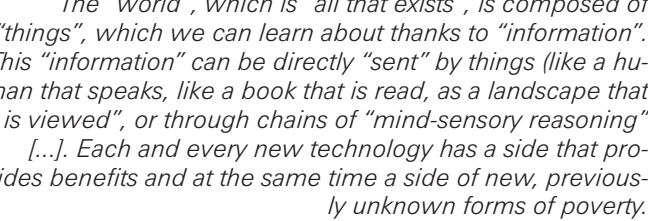

Stanistaw Lem - Bomba megabitowa ${ }^{2}$

In a period of the dynamic development of the oversupply of electronics and software, we are being assaulted by a multitude of solutions that have entered our everyday lives. Is technology its slaves through implementing the paradigm of the information society? Or are we, accidentally, searching for pretexts to use novelties and gadgets because we are dependent on them and they of ten are an escape from reality into a virtual world for knowledge or or one that quenthes our thirs tasks that had previously been performed by the protezy ( $w$ sensie przedłużenia naszych zdolności, umiejętnosci, czy tez sensoryki) jawią się jako rozwiązania idealne, ale czy na pewno?

Obecnie zauważyć można dwa skrajne nurty w wynalazczości: z jednej strony powstają śmiałe wizje nowych urządzeń które sa tak zaawansowane, iż nie wiemy czy aby realne, a z drugiej sprzedawana jest dość powszechna technika, któr przez lepsza reklame prezentowana jest jako efektywniejsza przetomowa. Sprytny marketing oferuje nam nowe poje-

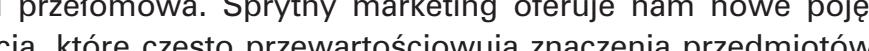
urzadzeń i rozwiazań, ponewż nie możn jeszcze korzystać z ogólnie dostepnej pzoci

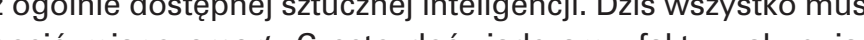
nosic miano smart. Często dosw iż mode rozopzedie. W trakcie użythowa tychż przedmiotow swerdzany, ze tak naprawde nie sa one bardzie miotow stwierdzamy, że tak naprawden nie sa one bardziej efektywne od tychy zersych techologicznie, a co za tym idzie nie mozna ich nazwac przelomowymi. Nie czeka nas zadna rewolucja technologiczna, ale stopniowa ewolucja pozwalająca sprzedawać obecne zdobycze techniki przez dług zas, by przynosily zyski koncernom.

Niniejszy artykuł opisuje interesujące przykłady rozwiązan prezentowanych na Smart City Expo - World Congress 2017 - Empower Cities. Empower People ${ }^{3}$ - w dniach 14-16 listopada 2017 roku, ktore, w mniemaniu autora, mają szansę stac się bardziej powszechnymi i są warte przedstawienia większej liczbie osób.

Obecnie procesy kształtujące współczesne miasta i metropolie, bardziej niż kiedykolwiek, formują nasz świat za sprawa nieustannie rosnącej populacji. Wyzwania i potrzeby, przed jakimi stoimy, są ogromne i tylko dzięki wspólnej kooperacji będzie można im sprostać. Przewidywany wzrost populacji ludzi w ciągu najbliższych kilku dekad dotyczy wielkości ok. 2.5 miliarda i skoncentruje sie przede wszystkim w re gionach: Azji oraz Afryki. Ponad podziałem terytorialnym, czy państwowym, nowoczesne metropolie i inne struktury urbanistyczne powinny razem wspótpracować, aby stawic czoła podobnym, wspólnym wyzwaniom, jak: zmi aby stawic tu, zattoczenie i zaniecyszczenie, brak odpowiednich oraz przystennych cenowo mieszań, edukcia stużba zdowia, integracia uchodźcow, czy migrentów. Poprawa to ciagly pregracja ḱry ma swoje misce w spolecznościach i oagly

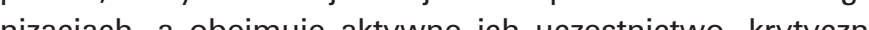

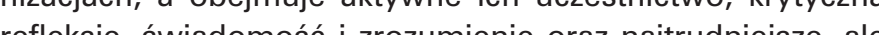
refleksje, sw wado mosc i zrozumienie oraz najtrudniejsze, ale wažne - dostęp i kontrolę nad ważnymi decyzjami i zasobami, w duchu szacunku i poszanowania srodowiska. Miasta sa jednostkami samorządowymi często lepiej przygotowanym do działania niż władze administracji panstwowej, przez co realizują swoją politykę (takze przestrzenną) oraz są w stanie skuteczniej rozwiązac problemy globalne, dlatego należy zapewnic im odpowiednie wsparcie. To właśnie te struktury są największymi beneficjentami postępu technologicznego. Tu właśnie będzie się rozwijał nowy potencjał gospodarczy, w oparciu o wspołpracę srodowisk akademickich i badawczych, samorządów lokalnych, nowoczesnego przemysłu informatyzacji oraz produktów pochodnych. Technologia jest tu kluczowa i pozwala na transparentnośc decyzji organow
Modern prostheses (in the sense of expanding our Wons, but are they, really?

We can currently observe two radical currents in innovation: bold visions of new devices that are real on the one hand, while on the other we are being sold common technology which is presented as ever more effective and ground-breaking by advertisements. Clever marketing offers us new terms, which often re-evaluate the importance of tems, devices and solutions because we still cannot make use of widely accessible artificial intellten experience this fact fact when purchasing the latest solutions that are much better packaged tha previous models. During the use of these items we come to the conclusion that they are not actually any more effective than older ones in terms of technology and, as a resul, we cannot call them ground-breaking. Instead of a pending technologtion that makes it possible to sell current technica achievements over a long period of time so that they can bring profits to corporations.

This article describes interesting examples of solutions that were presented at the Smart City Expo World Congress 2-17 - Empower Cities. Empower 16th of Nhich to 2017 , a benthen the 14 th and 16th of November 2017, and which, in the author's mon are worthy of being presented to a wider audience.

Currently, more than ever the processes that shape modern cities and metropolises, shape our world due to the constantly growing population. The challenges and needs that we face are will we be able to ovarcome them. Theoperation human population increase for the next couple of decades revolves around 2,5 billion people that will mostly concentrate in the regions of Asia and Africa. Standing above territorial or state divisions, modern metropolises and other urban structures should cooperate with each other in order to face similar common challenges like climate change, housing, eduction, healthcar, the integration of refugees or migrants. Improvement is a continuous process which has its place in communities and organisations and includes their active participation, critical reflection, awareness and understanding and, what is the most difficult, yet important - access and control over important decisions ment. Cities are municipal entities that environbetter prepared to act than centrat government authorities, which is why they are able to more effectively solve global problems by implementing their policies (including spatial ones), which is why we should give them appropriate support. is these structures that are the greatest beneficianew ef technological progress. It is there that the new economic potential, based on the cooperagovernments and modern industry - digitalisation and its derivatives - will materialise. Technology is 
władzy oraz partycypację społeczną, wzmocnienie roli miesznych. To właśnie z użyciem nowych narzędzi sprawowanie demokracji może być lepsze i bardziej przejrzyste, a kontrola polityki sprawowana przez świadome społeczeństwo. Kongres: Smart City Expo jest zaangażowany w wdrażanie i monitorowanie wszystkich globalnych programów na poziomie krajowym i nie tylko. Wydarzenie jest platforma dla ksztattowania nowych dobrych praktyk, wspólnych polityk, do dzielenia sie firm, nawiazywania partnerstwa oraz wspótpracy, a takż platforma pzi, którzy nodej dzi, korzy podejnja wspolne wyzwania i gener ja moźliwo-

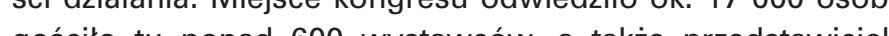
goscilo tu por wysokiego szzze z z ponad petów i przywodców czy wizjonerw. Konges zgomadzil najbardziej odpowiednich profesjonalistow I liderow wybitnie innowacyjnych miast, firm, przedsiębiorców, startupów, centrơw badawczych, inicjatyw i rozwiązan na swiecie, wraz ze strategiami na rzecz inteligentniejszego i bardziej zrównoważonego miejskiego świata. W strefie wystawowej uczestnicy zaprezentowall swoje najnowsze osiągnięcia, rzeczywiste rozwiązania i produkty, ktore dzięki technologii wywieraja konkretny i trwały, pozytywny wpływ na życie milionów ludzi. Wydarzenie jest częścią globalnej społeczności, ekosystemu zaangażowanego w tworzenie skutecznych rozwiązań, które pomogą rozwinąć gospodarkę pluralistyczną, poprawić jakość życia i promować zdrowszą przyszłość.

Fira Barcelona Gran Via - to obiekt wystawienniczy wykorzystywany do organizacji Międzynarodowych Targów, położony na południowy-zachód od centrum miasta. Światowy Kongres Smart City Expo, mieszczący się w tym budynku, nieustannie promuje dyskusje i tworzy synergie z ważnymi kwestiam zogniskowanymi wokół 8 tematów. Utworzona platforma dla ekspertów i uczestników ksztattuje możliwość dzielni d wiedza i rozwiazzaniami aktualnymi dla nowoczesnych miast:

\section{Zarządzanie - Co dzisiaj oznacza dobre zarządzanie?}

Wspótpraca między miastami, wspólne korzystanie społeczne, platformy współpracy, e-demokracja, e-administracja, wielopoziomowe sprawowanie rządów, otwarte dane (open data), otwarty rząd, otwarte innowacje, polityka, współpraca publiczno-publiczna, usługi publiczne, integracja usług

\section{Zrównoważony rozwój - Miasta prowadzące globalną} walkę ze zmianami klimatu

Zanieczyszczenie powietrza, zasoby alternatywne, zmiana klimatu, energia, geoinformacja, tereny zielone, budownictwo ekologiczne, inteligentne systemy budowlane, emisje gazów cieplarnianych, budownictwo mieszkaniowe, oswietlenie niskoemisyjne, przestrzenie publiczne, wzrost liczby ludności, rewitalizacja, rozwój regionalny, energia odnawialna rozwó obszarów wiejskich, inteligentne sieci, planowanie strategiczne, projektowanie urbanistyczne, planowanie i rozwój obszarów miejskich, rolnictwo miejskie, meble miejskie, narzędzia, gospodarka wodna, gospodarka odpadami, zero energetyczne. key here, it enables the transparency of decisions by government organs and public participation, increasing the role of residents and providing a beter functionality to urban structures.

It is with the use of new tools that implementing and control of politics can be performed by an informed society. The Smart City Expo World Congress is involved in the application and monitoring of all global programmes at the state level and beyond. The event is a platform for the shaping of new good practices, sharing research results, companies, entering into partnering relations and cooperation, as well as a networking platform fo all cities, connecting people who undertake common challenges and generate opportunities for action. The event was visited by around 17000 people and had over 600 exhibitions, in addition to featuring high ranking representatives from over 650 cities and over 400 experts and leaders or vipriate professionals and leaders of extraordinarily innovative cities, companies, entrepreneurs, start ups, research centres, initiatives and solutions in the entire world. In the exhibition area the visitor presented their latest accomplishments and rea solutions and products, which - thanks to technol ogy - exert a concrete and stable positive influence on the a cos of millons of people. The event is gaged in the creation of effective solutions that will help in the development of a pluralist economy, the improvement of the quality of life and the promotion of a healthier future.

Fira Barcelona Gran Via - is an exposition structure used to organise International Expositions, located to the south-east from the city centre. The Smart City
Expo World Congress that is located in this building ceaselessly promotes discussion and creates a synergy between various problems focused around 8 topics. The platform for experts and participants that has thus been created shapes the ability to share knowledge and current solutions for modern cities:

\section{Govern
today?} City-to-city cooperation, commons, cooperation plattorms, data maturity, e-democracy, e-governdata, open government, open innovation, policy framework, public-public cooperation, public services, service integration, transparency.

Sustainability - Cities that lead the global fight against climate chang.

Air pollution, alternative resources, climate change,
energy, geo-information, green areas, green building, intelligent building systems, greenhouse ga emissions, housing, lighting, low carbon, open space, population growth, public space, regeneration, regional development, renewable energy rural development, rural grids, smart grids, strategic planning, urban design, urban planning an
development, urban farming, urban furniture, utilities, water management, waste management, zero carbon.
3. Mobilność - Czy mobilność w mieście powinna być sterowania?

Samochód elektryczny, autonomiczny transport, komunikacja rowerowa, transport towarowy, optymalizacja logistyki, platformy integracyjne, inteligentne systemy transportowe, mobilność jako usługa, multimodalny system transportowy, niezmotoryzowana mobilność, parking, strategia dla pieszych transport publiczny, realne dane w czasie, transport wspótdzielony, zrównoważona mobilność w miastach, zarządzanie ruchem, węzły transportowe, sieci transportowe.

4. Circular Economy - Podejmowanie działań transformacyjnych w przyszłości

Niebieska gospodarka, model biznesowy, zamknięta pẹtla, ekoprojekt, żywność, zielony przemyst, symbioza przemysłowa, tworzenie miejsc pracy, niskoemisyine rozwiązania, logistyka dla obiegu, przepływ materiałów, opakowania, tworzywa sztuczne, produkt jako usługa, produktywne miasta, recykling, regeneracja, efektywne gospodarowanie zasobami ponowne wykorzystanie, naprawa, tekstylia, górnictwo miejskie, zero odpadów.

\section{Bezpieczne miasta - Zwiększenie bezpieczeństwa na-} szych mias

Cyberbezpieczeństwo, ochrona danych i prywatność, odtwarzanie po awarii, sytuacje awaryjne, prawodawstwo, bezpieczeństwo publiczne, regulacje, odporność, zarządzanie ryzykiem, technologie bezpieczeństwa, nadzór

6. Społeczeństwo - Wzmocnienie pozycji ludzi w celu sprostania wyzwaniom społecznym

Starzenie się społeczeństwa, współżycie, wspóttworzenie, współprodukcja, kultura, podział cyfrowy, edukacja, e-zdrowie, e-learning, wzmocnienie pozycji, sprawiedliwość, płeć zdrowie, integracja, nierówność, wiedza, żywe laboratoria uczestnictwo, wzrost populacii, jakość ̇̇ycia, prawo do miasta, innowacje społeczne, usługi społeczne, dobrobyt.

7. Gospodarka - Dlaczego nowe gospodarki miejskie maja 7. Gospodarka - Dlaczego nowe gospodark
sens w aspekcie zrównoważonego rozwoju

Odpowiedzialność, nowy model biznesowy, model współpracy, przedsiebiorczość, rozwój, finansowanie, inwestycje, zamówienia publiczne, produsage, partnerstwo publiczno-pryzamówienia publiczne, produsage, partnerstwo publiczno-prylenia się, ekonomia społeczna, startup, wartość użytkownika.

8. Dane i technologia - Jak przełomowe technologie zmieniają kształt miast

Zaawansowane analizy, duże zbiory danych, technologia blockchain, analiza biznesowa, chmura, platforma miejsk sieci komputerowe, centrum danych, zarządzanie danym wizualizacja danych, modelowanie cyfrowe, technologie de strukcyjne, rozproszone architektury, drony, geoinformacja, rozwoj sprzętu, technologie informacyjne, rozwoj infrastruktury, Internet, interoperacyjność, infrastruktura sieci, robotyka, czujniki i łączność, integracja usług, rozwój oprogramowania, telekomunikacja.
3. Mobility - Should mobility within a city be controlled?

Connected \& self-driving vehicle, cycling, electric vehicle, freight, logistics optimization, integration as a service, multimodal transport system, nonmotorized mobility, parking, pedestrian strategy, policy framework, public transport, real-time data shared transportation, sustainable urban mobility traffic management, transport hubs, transportation networks.

4. Circular Economy - Undertaking transformation efforts in the future.

Blue economy, business model, closed loop, design for circularity, eco-design, food, green indusry, industrial symbiosis, job creation, low carbon, logistic for circularity, material flow, packaging, plastics, product as service, productive cities, recycturing reseurce efficiency, re-use, repair, supply chain, textile, urban mining, zero waste.

5. Safe cities - Increasing the safety of our cities. Cyber security, data protection and privacy, disaster recovery, emergencies, legislation, public safety, regulation, resilience, risk
security technologies, surveillance.

6. Safe cities - Strengthening the position of people in order to meet social challenges.

Ageing population, society, co-creation, co-production, culture, digital divide, education, e-health, e-learning, empowerment, equity, gender, health, inclusive, inequality, knowledge, living labs, participation, population growth, quality of life, right to the

7. Economy - Why new urban economies make sense in the aspect of sustainable development.
Accountability, new business model, cooperation model, entrepreneurship, development, financing, investing, public procurement, prod-usage, public-private-people partnership, public value, shared value, sharing economy, social economy start-up, user value.

8. Data and technology - How ground-breaking technologies change the shape of cities?

Advanced analytics, big data, block chain, business intelligence, cloud, city platform, computer networking, data centre, data management, data visualization, digital modelling, disruptive technologies, distributed architectures, drones, geoinformation, hardware development, information interoperability, network infrastructure, robotics, sensors and connectivity, service integration, software development, telecommunications.

The Smart City Expo 2017 World Congress featured over 50 official pavilions from all over the world. Cities and countries were often represented through shared pavilions in order to promote loca A significant number of international pavilions received funding from governments, institutions and industries. 
Kongres Smart City Expo 2017 posiadał ponad 50 oficjalnych pawilonów z całego świata. Miasta i kraje reprezentowały często wspólne pawilony, aby promować lokalne firmy, nawiązać kontakty oraz współpracę. Znaczna liczba pawilonów międzynarodowych otrzymała wsparcie od rządów, instytucii, czy branż. Ponadto wystawcy to firmy, korporacje, miasta, państwa, rządy i jednostki samorządowe, instytucje.

Kongres zgromadzit ponad 400 światowych liderów i innowatorów, aby dzielić sie wiedza, debatować nad wyzwaniami, przed którymi stojá nasze miasta, zachecać do myślenia i inspirować ogól śśniatowe wezwanie do dziania w celu

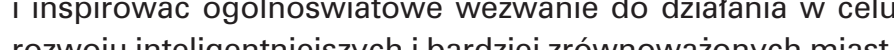

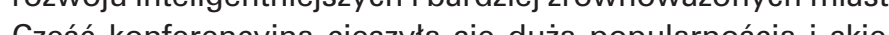
Częsc konferia rowana byla zaóno do odwiedzajacych jak i specjalistow. Osoby prowadzace panele inystepuace w roli mowcy, to zajmujący wysokie stanowiska przedstawiciele firm global-
nych, jednostek samorzadowych z całego świata, profesoronych, jednostek samorządowych z całego świata,
wie akademiccy, urzednicy, artyści i dziennikarze.

wie akademiccy, urzędnicy, artyści i dziennikarze.
Smart city - inteligentne miasta - należy to pojejcie rozumieć Smart city - inteligentne miasta - należy to pojęcie rozumieć
nie tylko jako rozwiazania elektroniczne, systemy aplikacii, ale nie tylko jako rozwiazzania elektroniczne, systemy aplikacji, ale jako sprawne zarządzanie miastem oraz zasobami ludzkimi. Żadna maszyna czy sztuczna inteligencja nie jest obecnie tak rozwinięta, aby zmierzyé się z kompleksowymi problemam współczesnych metropolii, w przeciwieństwie do śmiałych wizjonerów, zespolow fachowcow, ktorzy zajmują się poprawą życia i rozwiązywaniem problemów w strukturach zurbanizowanych na całym świecie.

Współczesna urbanizacja dokonuje się tak szybko, że gdybyśmy chcieli to zwizualizować musielibyśmy sobie wyobrazić że co 3 miesiące przybywa na Ziemi populacja równa Londynowi. $Z$ kolei problemy planistyczne polegają na nieustannym planowaniu, a nie jednorazowym stworzeniu planu, co było kwestią poruszaną na konferencji. Dzięki takim rozwiązaniom, można interaktywnie i na bieżąco odpowiadać na nieustannie nowo powstające problemy miast. Inny przykład dotyczył innowacyjnego podejścia do rynku nieruchomości. Modelowe rozwiązanie wprowadzone przez Wiedeń ${ }^{4}$ przedstawione zostało jako mieszkania socjalne dla społecznej integracji. Miasto jest właścicielem znacznej części nieruchomości i realizuje polityke budownictwa socjalnego od 35 lat. Cechuje je różny standard odpowiedni dla każdego odbiorcy niekoniecznie naibiedniejszego. Mieszkania te nie trafiaja na rynek wtórny, lecz są ciaggle wynajmowane, a zyski inwestowane $w$ budowe nowych. Jest to misja miasta. Socjalne budownictwo służy wyrównywaniu nierówności społecznych ${ }^{5}$. Z innej strony skrytykowano rynek mieszkań na krótkotrwały wynajem przytaczając dane swiadczące, iz największym udziałowcem jest tu branża hotelarska, a nie, jak sądzono wcześniej, drobni inwestorzy. Wypowiedziom towarzyszyły żywe dyskusje, w ktorych nie zawsze podzielana stanowisko mówców. Podczas jednego panelu dyskusyjnego osoba z publiczność wyszla na scenę i zakomunikowała swoje kontrowersyjne zdanie, iż nic z tych rzeczy, które zostały zaprezentowane na targach nie jest jej koniecznie potrzebne do życia, oraz że o tym wszystkim można przeczytać w Internecie. Mężczyzna ten poddał pod wątpliwość nazewnictwo inteligentnych rozwiązań, które nie wnoszą niczego, co byłoby przełomowe.
The Congress gathered over 400 world leaders and innovators in order to share knowledge, debate on challenges faced by our cities, encourage thinking and inspire a global call to action in orde to develop smarter and more sustainable cities.
The conference section was highly popular and was directed to both visitors and specialists. Th persons who moderated the panels and acted as speakers were high-ranking representatives from global companies, local government entities from
all over the world, academic professors, officials, all over the world, aca
artists and journalists.

Smart city - intelligent cities - should be undertion systems, but as effective forms of governing cities and human resources. No machine or artficial intelligence is currently advanced enoug to face the complicated problems of modern metropolises, contrary to bold visionaries and team of professionals who work on improving lives an solving problems within urbanised structures all over the world.

Modern urbanisation is taking place so fast that if we were to visualise it, we would have to imagine equal to that of the residents of London every months. In turn, planning problems are based on continuous planning instead of developing a single plan, which was a subject that was discussed can interactively and cont hese solutions we ceaselessly emerging problems of cities. A different example featured an innovative approach to the real estate market. The model solution that had been introduced by Vienna ${ }^{3}$ was presented as social housing for social integration. The city is the owner of a sizeable amount of real estate 35 years. It features a policy of social housing for ate for all types of consumers, not necessaily the poorest ones. These apartments do not enter the secondary market but are continuously leased and the profits are invested in the construction of new ones. This is the city's mission. Social housing is meant to even out social inequalities. On the other hand, the residential market was criticised for greatest share is in the hands of the hotel that the and not, as it had been previously thought, smal developers. The presentations were accompanied by lively discussions that did not always share the position of the speakers. During one discussion panel, a member of the audience took to the stag and communicated their controversial statement that none of the things that were being presented
at the expo was necessary for them to live, as well as that all of it could be read about on the Internet. The man doubted the naming of smart solutions which do not provide anything ground-breaking. It was an interesting voice in a discussion, which invites us to reflect on the subject of the need to create many products or the triumph of content over viable compromise for the future of circulation only transport Car sharing or the sharing of other possessions are individual large-scale solutions. Public transport builds a community's capacity for
Był to interesujący głos $w$ dyskusji, skłaniający do refleks treści nad funkcj krócia. Wielu produktow, czy przerostu dyny słuszny kompromis dla przyszłości komunikacji i transportu. Car sharing - współdzielenie się samochodem i innymi własnościami to rozwiązania indywidualne o dużej skali. Publiczny transport buduje zdolność społeczności do zmian i przełamywania barier ${ }^{6}$ a słusznym kierunkiem rozwoju sa inwestycje w publiczna komunikacje zbiorowa oraz rowerowa. Inne nowe trendy jakie zaprezentowano dotyczyly zagadn. żywności oraz jej produkcii, co możn byto zobaczyć szczegónie w pawilonie Estoii. Takie interesiacym w zy ności ekologicznej, nie tylko na etapie produkcji, ale również podczas transportu aż pod drzwi.

Kolejnym ważnym elementem programu była ceremonia wręczenia nagród, podczas której przyznano nominacje i nawręczenia nagrod, podczas której przyznano nominacje i nagrody dla najbardziej innowacyjnych rozwiazzan wpisujących się w trend oraz tematyke Expo, zarowno wa kategorlach zgloszonych projektow, dzialan, czy innowacyjnych idei. Warto tu wspomnieć o nagrodzonych, występujących w roli propagatorów nowych idei realizowanych z uzyciem technologii. Miasto Amsterdam - (Holandia) zostało nagrodzone za: Amsterdam Circular Innovation Program, który dotyczy gospodarki miejskiej rozwijanj woparciu o obieg zamknięty. Lokalna produkcja zywnosci zrownowazonej i sezonowej, energi elektrycznej, ograniczenie zużycia paliwa oraz poprawa przetwarzania odpadów w łańcuchu cyklu recyklingu, to sposób na wzajemną integrację wielu dziedzin.

Nagrodę za najbardziej innowacyjne projekty, które sa obecnie wdrażane $\mathrm{i}$ rozwijane $\mathrm{w}$ dziedzinie mobilności otrzyma koncern Seat, (Barcelona - Hiszpania), który zaprezentował ułatwienia mobilności w miastach: w erze cyfrowego świata? Jest to nowa koncepcja mobilności, która stawia na pierwszym miejscu wspólne, zintegrowane usługi mobilności. Obejmuja one swoim zakresem wspótdzilonie samochodów i moìliwosi, jakie daje gospodark dzielenia sie jednoczénie dostosowując się do zachodzących procesów cyfryzacji życia.

Korporacja ZTE (Shenzhen - Chiny) otrzymała nagrode Wor dziedzinie Smat Wu wa najzardziej inn Wucyine projekty, które sa obecnie woda za najb i

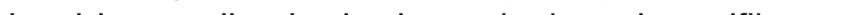
nia tej innwoji opiedaja sie na zudowaniu zunifikowanej bezprzewodowej sieci rządowej, zapewniającej bezpieczny iniezawodny dostęp do szerokopasmowego oraz dedykowanego bezprzewodowego kanalu transmisji danych. Obejmuje to równiez budowę Urban Big Data ${ }^{6}$, - platformy Wuhan $w$ chmurze internetowej oraz inteligentnych aplikacji przemysłowych w sektorze mobilności.

Nagrodę za najbardziej innowacyjne projekty, wdrażane, rozwijane w dziedzinie danych i technologii otrzymała Krolewsk Komisja - Yanbu - (Arabia Saudyjska). Projekt Smart City, którego celem jest poprawa jakosci zycia obywateli, polega $n$ wdrozeniu nowej sieci światłowodowej, stworzeniu inteligentnego systemu sterowania oświetleniem, poprawie system mobilności, stworzeniu platformy do dużych zbiorów danych i opracowaniu zintegrowanej platformy komunikacyjnej (ICP). change and breaking barriers 5 and the proper $\mathrm{di}$ rection of development are projects that invest public mass and bicycle transport.

Other trends that were presented focused on which was particularly visible in Estonia's pavilion. An Austrian project also appeared to be interesing, as it was based on the monitoring of the quality of green food, not only during the productio stage, but also over the course of its transport to one's doorstep.

Another important element of the programme was the Awards Ceremony, during which nomination solutions fitting in with the trend and theme of the Expo, in the categories of projects, efforts or innovative ideas. It would be good to mention the prize-winners who acted in the role of propagators of new ideas that were implemented using technologies.

The City of Amsterdam (The Netherlands) received Program, which is focused on an urbar Inovatio based on closed circulation. Local production of sustainable and seasonal food, electric power, limiting fuel consumption and an improvement of waste processing in the recycling chain is a method of mutually integrating many fields.

The award for the most innovative projects that are currently being implemented and developed corporation, (Barcelona - Spain), which had pre sented the Easy Urban Mobility: Towards the Digital World project. It is a new concept of mobility, which places common, integrated mobility services first. They include car sharing and the possibiliies provided by a sharing economy, while simultaneously adapting to the on-going processes of the The ZTE - cor

en an award for the Smart Wuhan loT and Big Dat Reality projects in the category of the most innovative projects that are currently being implemented and developed in the sphere of safe cities. The assumptions of this innovation are based on building a unified wireless government network, which can Internet and a dedicated wireless data transmis sion channel. It also includes the establishment of Urban Big Data ${ }^{6}$ - a Wuhan cloud-based platform and smart industrial applications for the mobility sector.

The award for most innovative data and technology projects that are currently being implemented for developed was given to the Royal Commission project, whose aim is to improve the quality of life of citizens, is based on implementing a new optical fibre network, creating a smart lighting control system, improving the mobility system, creating a platform for big datasets and developing an integrated circulation platform (ICP).

The Dubai Smart Office - (Dubai - United Arab chain Initiative, for being the first smart city supported by Blockchain technology' in specific government services and in the creation of an industry 

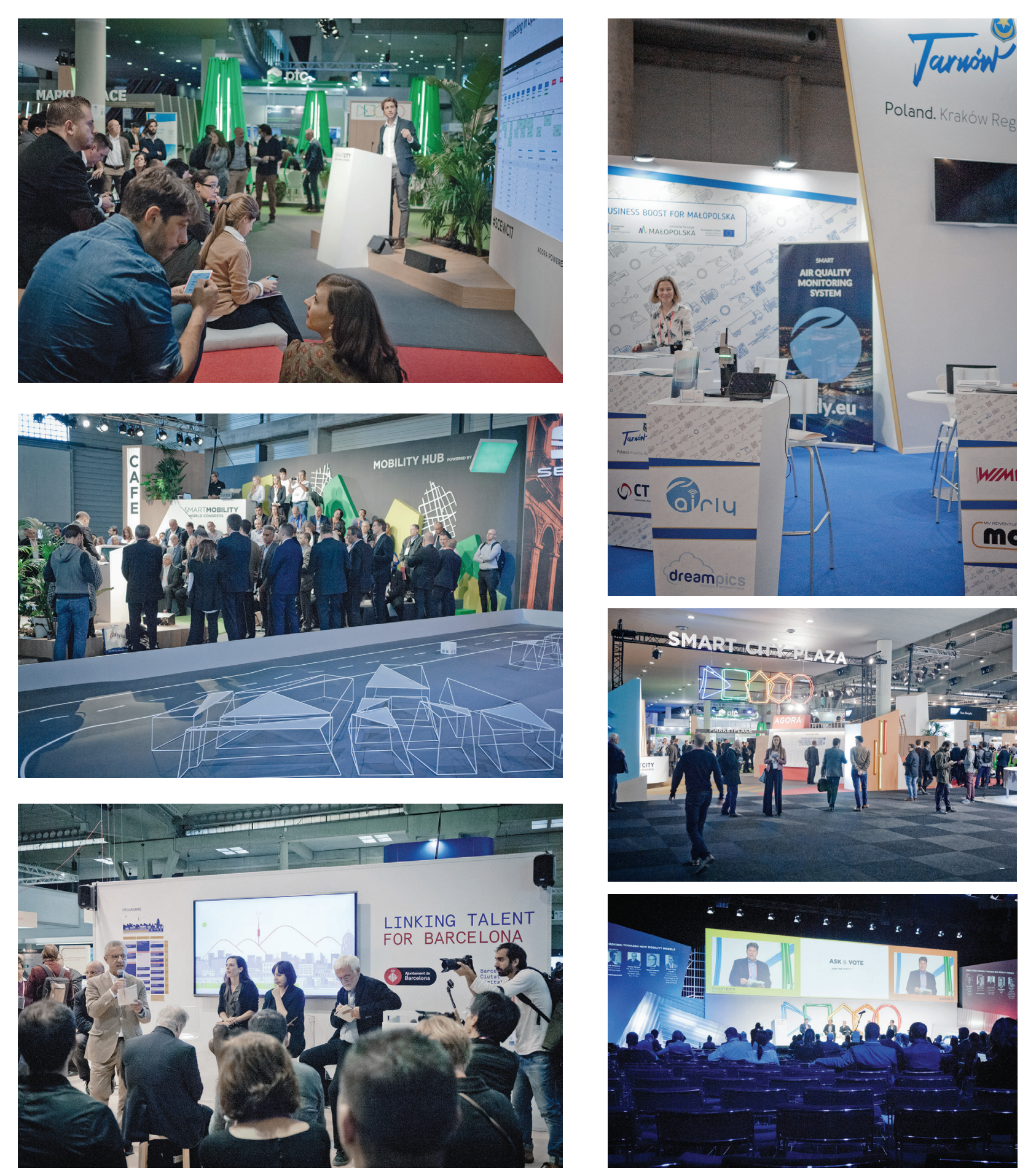

II. 1-6. Smart City Expo, fot. Piotr Celewicz/Smart City Expo, phot. by Piotr Celewicz

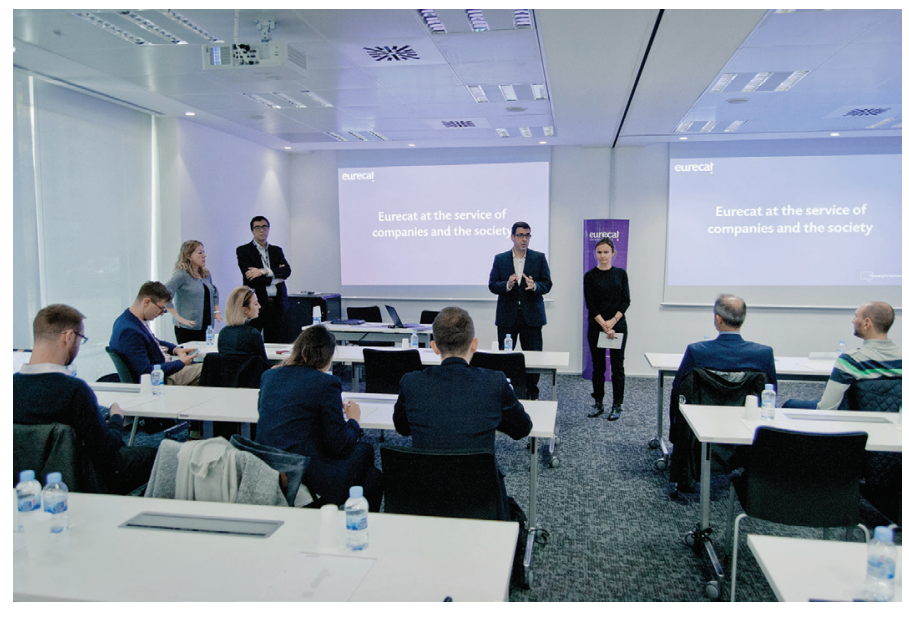

Dubai Smart Office - (Dubaj - Zjednoczone Emiraty Arabskie) nagrodzono za Dubaj Blockchain Initiative Pierwsze inteligentne miasto wspierane przez technologię Blockchain ${ }^{9}$ w odpowiednich usługach rządowych i w tworzeniu branży umożliwiającej start-up-y. Nagrodę przyznano miastu, które demonstruje strategie, inicjatywy i polityki, opracowane dla swych obywateli.

Buenos Aires City - Buenos Aires - Argentyna zostało nagrodzone za program ochrony żywności w obszarze rozwoju miejskiego i ma na celu wdrożenie zrównoważonej polityki żywnościowej. Projekt dziala na izecz podnoszenia świadomości społecznej z tematyki marnotrawienia żywności i zmiany wzorców konsumpcji zywnosci przez wdrażanie inicjatyw recyklingu, a także świadomej edukacji.

Nagrodę za koncepcję, która przyczynia się do pomyślne transformacji miast w celu osiagnnięcia zrównoważonego zintegrowanego rozwoju na każdym etapie, otrzymał Marketplace.city z Chicago - (Stany Zjednoczone). Jest to to platforma umożliwiająca innowatorom z sektora publicznego poszukiwanie, badanie i wdrażanie nowych rozwiązań technologicznych. Platforma koncentruje się na potrzebach i wynikach miasta, rekomendujac odpowiednie produkty, rozwiązania oraz studia przypadków, wdrożone w innych miastach.

Międzynarodowy kongres to okazja, która umożliwia spotkania najwyższych światowych interesariuszy, aby wymienić sie doświadczeniami, pomystami, nawiazać cenne kontakty skut kuja podpion pón miznesow skut badawczych it Ponadto to potencjat w stuzacy promowan firm podczas glon kodzas globar

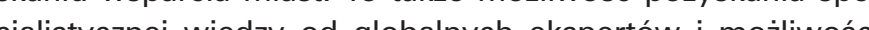

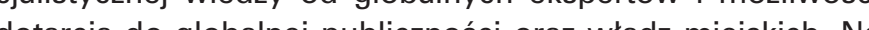

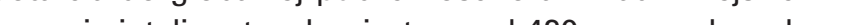
szczycie intligenty tow uczestniczylo w kluczowych debatach dotyczących zathe

Międzynarodowo Expo to okazja do zaprezentowania swoich projektów i rozwiązania potencjalnym klientom rozwijania współpracy z krajami, miastami, uniwersytetami, inwestorami, start-up'ami. To takze możliwosć skorzystania z bardzo popularnych działań, takich jak Event Brokerage (działalność
11. 7. Centrum innowacij - Eurecat, fot. Piotr Celewicz
Innovation centre - Eurecat, phot, by Piotr Celewicz

empowering start-ups. The award was given to a city that demonstrates strategies, initiatives and policies developed for their citizens. was given an award for its food protection programmes in the sphere of urban development tha was aimed at implementing a sustainable food polwy. The project wiks towinds increasing public food consumption patterns through implementing recycling initiatives and informed education.

The award for the concept that is aiding in the favourable transformation of cities in order to achieve sustainable integrated development at every stage was given to Marketplace.city of Chicago (United Shaves $\mathrm{Amom}$ the public sector to selentes inand implement new technological solutions. The platform concentrates on the needs and results of a city, recommending appropriate products, solutions and case studies implemented in other cities. The international congress is an occasion that gathers the highest global stakeholders to meet and share their experiences, ideas, form valuable connections contracts, research, etc. Furthermotional business a potential that serves to promote companies during a global reference event and obtain the support of cities. It is also an opportunity to obtain specialist knowledge from global experts and the possibility to reach a global audience, as well as municipal authordies. At his smart cities summin over 420 acknowedged speakers participated in key debates about

ent projects and solutions to potentialty to presvelops cooperation with states, cities, universities, investors and start-ups. It is also an opportunity to make use of very popular efforts like Event Brokerage (a matchmaking activity for potential business partners), the employment market or dedicated ences with experts from specific sectors. It is here that initiating cooperation with key decision-makers from a range of industries tied with smart cities, both from the private and the public sector has been made possible. 
pośrednictwa ang. Matchmaking activity - w zakresie kojarzenia partnerów biznesowych), rynek pracy lub dedykowane Side Events (wydarzenia poboczne), które obejmują warsztaty i konferencje z ekspertami z określonych sektorów. Tu właśnie jest możliwe zapoczątkowanie współpracy z kluczowymi decydentami pochodzącymi z wielu branż związanych z inteligentnymi miastami, zarówno z sektora prywatnego, jak i publicznego.

\section{PRZYPISY}

1 Wyjazd na Smart City Expo możliwy był dzięki udziałowi w programie Business Boost for Malopolska - Projekt partnerski realizowany przez Centrum Transferu Technologii Politechnika Krakowska oraz Urząd Miasta Tarnowa, którego celem jest wsparcie małopolskich MŚP w procesie internacjonalizacji oraz promocja oferty gospodarczej regionu. Oprócz kongresu dla uczestników wyjazdu przygotowano zwiedzanie centrów innowacji - prezentujących efektywniejsze zarządzanie bazą wiedzy - know how i wynalazkami.

${ }^{2}$ http://cytatybaza.pl/autorzy/stanislaw-lem.html

${ }^{3}$ Kongres Smart City Expo 2017 - Wzmocnij miasta. Wzmocnij ludzi.

${ }^{4}$ Bojan Schnabl - miasto Wiedeń

${ }^{5}$ Maria Sisternas Tusell - CEO MEDIAURBAN

${ }^{6}$ Przywołany cytat Enrique Peñalosa - Prezydenta Bogoty

7 Easy Urban Mobility: Towards the Digital World

${ }^{8}$ Big data - termin odnoszący się do dużych, zmiennych i różnorodnych zbiorów danych, których przetwarzanie i analiza jest trudna, ale jednocześnie wartościowa, ponieważ może prowadzić do zdobycia nowej wiedzy[1]. W praktyce pojęcie dużego zbioru danych jest względne i oznacza sytuację, gdy zbioru nie da się przetwarzać przy użyciu trywialnych, powszechnie dostępnych metod[2]. W zależności od branży i stopnia złożoności algorytmu może to oznaczać rozmiar terabajtów lub petabajtów (np. analiza zderzeń czastek elementarnych w fizyce wysokich energii[3]), jednak w innych zastosowaniach będą to już megabajty bądź gigabajty (np. porównywanie billingów telefonicznych w telekomunikacji[4]). Big data ma zastosowanie wszędzie tam, gdzie dużej ilości danych cyfrowych towarzyszy potrzeba zdobywania nowych informacji lub wiedzy. Szczególne znaczenie odgrywa wzrost dostępności Internetu oraz usług świadczonych droga elektroniczną, które w naturalny sposób są przystosowane do wykorzystywania baz danych. https://pl.wikipedia.org/wiki/Big data

9 Blockchain lub łańcuch bloków (czasem też łańcuch blokowy) - zdecentralizowana i rozproszona baza danych $\mathrm{w}$ modelu open source $\mathrm{W}$ sieci internetowej o architekturze peer-to-peer (P2P) bez centralnych komputerów i niemająca scentralizowanego miejsca przechowywania danych, służąca do ksiegowania poszczególnych transakcji, płatności lub zapisów księgowych[1] zakodowana za pomocą algorytmów kryptograficznych. W istocie blockchain to swoisty zdecentralizowany i rozproszony rejestr transakcji lub mówiąc inaczej jest to zdecentralizowana platforma transakcyjna w rozproszonej infrastrukturze sieciowej. Blockchain to publiczny i jawny rejestr do którego dostęp może uzyskać każdy https://pl.wikipedia.org/wiki/Blockchain

\section{LITERATURA}

[1] Przewodnik po wydarzeniu

źródła internetowe: (stan na 30.11.2017):

http://www.smartcityexpo.com/

http://www.transfer.edu.pl/pl/businessboostformalopolska-.htm

http://www.tarnow.pl/Biznes/Business-Boost-For-Malopolska

https://pl.wikipedia.org/wiki/Blockchain

https://pl.wikipedia.org/wiki/Big data

\section{ENDNOTES}

1 The trip to the Smart City Expo was possible thanks to participation in the Business Boost for Małopolska programme - a partner project being carried out by the Cracow University of Technology, Technology Transfer Centre and the Office of the City of Tarnów, whose aim is supporting small and medium-sized businesses from Małopolska in the process of internationalisation, as well as the promotion of the economic offer of the region. Apart from the congress, a visit to innovation centres - which present a more effective form of knowledgebase management, including know how and inventions - was prepared for the participants of the trip.

2 http://cytatybaza.pl/autorzy/stanislaw-lem.html

${ }^{3}$ Bojan Schnabl - the city of Vienna

${ }^{4}$ Maria Sisternas Tusell - CEO MEDIAURBAN

${ }^{5}$ A quote by Enrique Peñalos - the President of Bogota

${ }^{6}$ Big data - a term referring to large, changing and diverse datasets, the processing and analysis of which is difficult, but at the same time valuable, because it can lead to obtaining specific knowledge [1]. In practice, the concept of a large dataset is relative and means a situation when a set cannot be processed using trivial, widely accessible methods [2]. Depending on the sector and complexity level of an algorithm, it can mean a size measured in terabytes or petabytes (e.g. an analysis of the collisions of elementary particles in high energy physics [3]), however, in other implementations these can be megabytes or gigabytes (e.g. the comparison of phone billings in telecommunications [4]). Big Data is implemented everywhere where large amounts of digital data are accompanied by the need to gather new information or knowledge. Of particular significance is the growth of Internet access and electronic services, which are naturally adapted to using databases. https://pl.wikipedia.org/wiki/Big data

7 Blockchain, block chain (sometimes also chain of blocks) - a decentralised and distributed open source model database on an Internet network using a peer-to-peer architecture (P2P), without central computers and no centralised data storage, serving to keep track of individual transactions, payments or bookkeeping entries [1], encoded using cryptographic algorithms. In essence, a blockchain is a sort of decentralised and distributed transaction registry, or, in other words, it is a decentralised transaction platform in a distributed network infrastructure. Blockchain is a public and open registry that can be accessed by anyone. https:// pl.wikipedia.org/wiki/Blockchain

\section{BIBLIOGRAPHY}

[1] Event guide

[2] Kreft, J. „Za fasadą społeczności. Elementy zarządzania nowymi mediami." Wydawnictwo Uniwersytetu Jagiellońskiego, Kraków 2015, p. 61

online sources: (retrieved on 30.11.2017):

http://www.smartcityexpo.com/

http://www.transfer.edu.pl/pl/businessboostformalopolska-. htm

http://www.tarnow.pl/Biznes/Business-Boost-For-Malopolska

https://pl.wikipedia.org/wiki/Blockchain

https://pl.wikipedia.org/wiki/Big_data 